\title{
Intestinal intraluminal injection of glutamine increases trolox total equivalent antioxidant capacity (TEAC) in hepatic ischemia-reperfusion. ${ }^{1}$
}

\author{
Injeção na luz intestinal de glutamina aumenta a capacidade anti-oxidante total em \\ equivalência ao trolox (TEAC) na isquemia-reperfusão hepática.
}

\author{
Alberto Bicudo Salomão ${ }^{2}$, José Eduardo Aguilar-Nascimento ${ }^{3}$, Sandro Percário $^{4}$, Victor Sano $^{5}$, Nicole Ribeiro Marques 6 , \\ Claudia Cristina Gomes de Oliveira Dias ${ }^{6}$.
}

1. Department of Surgery, University of Mato Grosso, Cuiabá, Brazil

2. MD, Department of Surgery, Federal University of Mato Grosso, Brazil

3. MD, PhD, Chairman Full Professor, Department of Surgery, Federal University of Mato Grosso, Brazil

4. PhD, Associate Professor, Federal University of Para, Brazil.

5. MD, Affiliate Professor, Federal University of Mato Grosso, Brazil

6. Graduate Student, Medical School, Federal University of Mato Grosso, Brazil

\begin{abstract}
Purpose: To evaluate the effects of intraluminal injection of glutamine on the serum trolox equivalent antioxidant capacity in an experimental model of ischemia-reperfusion of the liver observing the applicability of modifications on the original assay method. Methods: Thirty Wistar rats underwent laparotomy to perform a $20 \mathrm{~cm}$ blind sac of small bowel and occlusion of the hepatic hilo for 30 minutes and reperfusion for 5 minutes. Into the gut sac it was injected glutamine (glutamine group, $n=10$ ) or distilled water (control group, $n=10$ ). Ten other animals (sham group) underwent laparotomy without artery occlusion. Blood samples were collected for trolox equivalent antioxidant capacity assays in different temperature conditions, reagent quantities and time for spectrophotometer readings. Results: Total antioxidant capacity was significantly greater in glutamine group than in both control group $(1,60[1,55-1,77]$ vs $1,44[1,27-1,53])$ and sham group $(1,60[1,55-1,77]$ vs $1,48[1,45-1,59])$. Conclusion: Glutamine enhanced serum antioxidant capacity. The assay technique consistently reflected the changes in the antioxidant defenses in this experimental model.
\end{abstract}

Key words: Ischemia. Reperfusion. Liver. Glutamine. Small Bowel. Oxidative stress.

\section{RESUMO}

Objetivo: Avaliar em um modelo experimental de isquemia-reperfusão hepática os efeitos da injeção intraluminal de glutamina na capacidade anti-oxidante total em equivalência ao trolox (TEAC) do plasma, verificando a aplicabilidade de modificações ao método original de dosagem. Métodos: Trinta ratos Wistar foram submetidos a laparotomia e confecção de uma alça fechada de $20 \mathrm{~cm}$ de comprimento envolvendo o intestinal delgado distal seguido do clampeamento do hilo hepático por 30 minutos e reperfusão por 5 minutos. Na alça fechada foi injetada glutamina (grupo glutamina; $\mathrm{n}=10$ ) ou água destilada (grupo controle; $n=10$ ). Em dez animais (grupo sham) não foi realizado clampeamento hilar. Coletou-se sangue para dosagem da capacidade antioxidante total em equivalência ao trolox em condições modificadas de temperatura, proporções relativas dos reagentes e tempo de leitura sob espectrofotometria. Resultados: A capacidade antioxidante total foi significantemente maior $(\mathrm{p}<0.05)$ no grupo glutamina que no grupo controle $(1,60[1,55-1,77]$ vs $1,44[1,27-1,53])$ e grupo sham $(1,60[1,55-1,77]$ vs 1,48[1,45-1,59]). Não houve diferenças estatísticas entre o grupo controle e o grupo sham. Conclusão: A glutamina melhorou a capacidade anti-oxidante total plasmática. O método de dosagem refletiu consistentemente alterações na defesa anti-oxidante nesse modelo experimental.

Descritores: Isquemia. Reperfusão. Fígado. Glutamina. Intestino Delgado. Estresse oxidativo.

\section{Introduction}

In various clinical and surgical conditions an ischemic event may play a crucial role in the pathophysiology of cell damage. Reperfusion to reestablish the blood flow to the tissues after ischemia is fundamental in the management of this condition. However, reperfusion may be responsible for injuries for the whole organism that are most serious than the ischemic damage per $s e^{l}$. The conjunction of the pathophysiologic events and the severe clinical condition that follows is called ischemia and reperfusion injury (IRI). In modern hepatic surgery prevention of IRI is most important and relevant. Pringle ${ }^{2}$ in 1908 described the classical operative procedure to clamp the portal triad to control intra-operative hemorrhage. This procedure is currently used in trauma surgery and during resection of the liver ${ }^{3}$. Orthoptic liver transplantation may constitute 
a major prototype and good example of IRI in the liver. The formation of oxygen free radical in the ischemic tissues may play an important role in $\mathrm{IRI}^{4}$. Anti-oxidative natural defenses are innocuous to limit the huge formation of free radical that follows and thus, oxidative damage is eminent ${ }^{5}$. Among the various anti-oxidative systems it is thought that glutathione system is the major biological mechanism to antagonize the creation of these oxygen free radicals ${ }^{6}$. Glutamine is the most abundant amino acid in the plasma ${ }^{7}$. Glutamine is the principal fuel for the enterocytes and immune cells, and is avidly taken by the intestinal epithelium cell by both the lumen and blood poles ${ }^{8}$. Glutamine is fundamental for glutathione formation ${ }^{9}$. The liver is the most important reservoir of glutathione, which is composed of three amino acids connected in tandem: glycine, cysteine, and glutamate, that is derived from glutamine ${ }^{6}$. Aguilar-Nascimento et $a l^{10}$ showed that intraluminal injection of glutamine minimize intestinal injury and the afflux of neutrophils after small bowel IRI. They suggest the findings are probably due to the increase of the anti-oxidative defenses by the presence of glutamine. The search for substances with anti-oxidative properties are a challenge for investigators. Methods to evaluate the anti-oxidative status are most important in IRI because they can be use in many diseases and conditions ${ }^{11,12}$. However, it is very difficult to evaluate each component of the complex antioxidative system and their interactions ${ }^{13}$. Thus, various methods have been reported to measure the total antioxidative capacity of the serum ${ }^{14,15,16,17,18}$. However, most of them are time-consuming and expansive. Miller et $a l^{17}$ reported a colorimetric method for the evaluation of the anti-oxidative capacity of the serum that was posteriorly modified by Re et $\mathrm{al}^{19}$. This technique is based on the inhibition of the absorbance of the free-radical ABTS ${ }^{*+}$ by anti-oxidants, and on the relation of this radical cation with the anti-oxidant scavenger Trolox, which is the synthetic analogue of Vitamin E. This method is very easy to be performed and most accurate ${ }^{20}$. In this present study we aimed at evaluating the effects of intraluminal glutamine in the Trolox total anti-oxidative capacity (TEAC) in an animal model of IRI of the liver.

\section{Methods}

\section{Reagents}

Trolox (Aldrich Chemical Co® 23,881-3, USA), (6hydroxy-2,5,7,8-tetramethylchromane-2-carboxylic acid), was used as anti-oxidant. ABTS (Sigma-Aldrich ${ }^{\circledR}$, A1888, USA) - 2,2'-Azino-bis (3-Ethylbenzthiazoline-6-Sulfonic Acid) and potassium persulfate $-\mathrm{K}_{2} \mathrm{~S}_{2} \mathrm{O}_{8}$ (SigmaAldrich ${ }^{\circledR}$, P5592, USA) were used to prepare a solution containing the radical cation $\mathrm{ABTS}^{\cdot+}$. A saline solution (phosphate buffer - PBS) prepared by dissolving $1.48 \mathrm{~g}$ $\mathrm{Na}_{2} \mathrm{HPO}_{4}$ (Sodium dibase phosphate), $0.43 \mathrm{~g} \mathrm{NaH} \mathrm{PO}_{4}$ (Sodium monobase phosphate) and $7 \mathrm{~g} \mathrm{NaCl}$ (potassium chloride) in $1 \mathrm{~L}$ of distilled water, adjusting for a $\mathrm{pH}$ of 7.4 was used. A solution containing $20 \mathrm{~g}$ of N(2)-L-alanil-Lglutamine (Dipeptiven ${ }^{\circledR}$, Fresenius Kabi) was used in the glutamine group. ABTS was dissolved in the buffer solution at a concentration of $7 \mathrm{mM}$. The radical cation ABTS $\left(\mathrm{ABTS}^{++}\right.$) was produced by the reaction between the solution containing ABTS $7 \mathrm{mM}$ with potassium persulfate $2,45 \mathrm{mM}$ (final concentration) in a dark room for 12-16 hours. Trolox $(2,5 \mathrm{mM})$ was prepared dissolving $0.1294 \mathrm{~g}$ of trolox in $200 \mathrm{~mL}$ of buffer solution ${ }^{19}$. During the measurement it was used a $\mathrm{ABTS}^{\cdot+}$ working solution by diluting the radical $\mathrm{ABTS}^{\cdot+}$ solution in phosphate buffer solution $(\mathrm{pH}=7.4)$ until an absorbance of $0,70 \pm 0.02$ at room temperature of $25^{\circ} \mathrm{C}$.

\section{Experimental design}

Thirty male Wistar rats $(250-300 \mathrm{~g})$ from the Central Biotery of the Federal University of Mato Grosso entered the experiment. Firstly they were kept during three days at the Investigation Laboratory of the Medical Sciences School environment at a constant temperature $\left(25^{\circ} \mathrm{C}\right)$ in $12 / 12 \mathrm{~h}$ light-dark cycles, and receiving water and rat chow ad libitum for adaptation. All experiment follows the ethical guidelines of the Brazilian College of Animal Experimentation (COBEA). The animals underwent $5 \mathrm{~cm}$ median laparotomy under anesthesia with inhalatory ether associated with intramuscular infection of $50 \mathrm{mg} / \mathrm{kg}$ ketamin chloride. During the operation the ileo-cecal valve was localized and at this point a 3-0 cotton suture was passed and tied by a mesenteric breach to occlude the intestine. Twenty $\mathrm{cm}$ up to this distal suture another similar suture for occlusion of the proximal small bowel was done and a closed $20 \mathrm{~cm}$ length small bowel sac was created. A careful dissection of the hepatic pedicle was performed and the vascular structures were clamped by a Pringle maneuver using an atraumatic vascular clamp ${ }^{2}$. At the same time, the intestinal sac was punctured by a $13 \times 4.5 \mathrm{~mm}$ needle and either a $1 \mathrm{~mL}$ solution containing of $20 \%$ glutamine (glutamine group; $\mathrm{n}=10$ ) or distilled water (control group; $n=10$ ) was injected inside the gut lumen. A previous pilot study attested that this volume was enough to entirely fill the sac without promoting significant distention of the gut sac. In a third group of rats (sham group, $n=10$ ) the hepatic pedicle was not clamped and nothing was injected into the small bowel sac. After 30 minutes of ischemia the vascular clamp was released and reperfusion was allowed for five minutes. Blood samples (3-4 mL) from the thoracic posterior vena cava was obtained and then the animal was killed with an overdose of inhalatory ether. In animals from the sham groups blood samples were collected after 35 minutes of anesthesia and laparotomy. Animals were allocated in the various groups at random during operation. Blood samples collected in heparinized syringes were immediately centrifuged at $1500 \mathrm{rpm}$ for 20 minutes. Approximately $1.5 \mathrm{~mL}$ of the supernatant layer corresponding to the serum was placed in $2 \mathrm{~mL}$ tubes, frozen and stocked in liquid nitrogen until the time of the assay.

\section{Trolox Equivalent Antioxidant Capacity Curve}

A calibration curve for the Trolox equivalent antioxidant capacity was built by plotting different 
concentrations of Trolox (mM) versus its total equivalent antioxidant capacity. Table 1 show the concentrations used in the curve. Approximately $2970 \mu 1$ of the working solution containing the radical $\mathrm{ABTS}^{\cdot+}$ was pipetted and placed in plate of spectrophotometer. Absorbance at 734 $\mathrm{nm}$ was read and corresponded to T0. Thirty $\mu \mathrm{l}$ of trolox solution was added and the final solution was manually mixed for 20 seconds and then read it again at $734 \mathrm{~nm}$ and the value obtained after exact five minutes (T5) was registered. The assay was repeated in triplicate for each of the trolox dilution (A to $\mathrm{F}$ tubes). The antioxidant capacity was defined by the value of the difference between T5 and T0 divided by T0 ([T5-T0]/T0). For corrections related to the phosphate buffer the final value was lessened from the value observed in the $\mathrm{F}$ tube (white control). Figure 1 shows the pattern curve of the Trolox total antioxidant capacity correlated to its final concentration. The reaction is linear and of the first degree for the interval corresponded to a inhibition potential of about $40-80 \%{ }^{1}$.

TABLE 1 - Concentrations used to build the pattern curve of the total Trolox equivalent antioxidant capacity.

\begin{tabular}{lccc}
\hline Tube & $\begin{array}{c}\text { Trolox } \\
\mathbf{2 , 5 m M} \\
(\boldsymbol{\mu l})\end{array}$ & $\begin{array}{c}\text { PBS } \\
(\boldsymbol{\mu l})\end{array}$ & $\begin{array}{c}\text { Trolox } \\
\text { concentration } \\
(\mathbf{m M} \mathbf{)}\end{array}$ \\
\hline A & 5000 & 0 & 2,5 \\
B & 4000 & 1000 & 2,0 \\
C & 3000 & 2000 & 1,5 \\
D & 2000 & 3000 & 1,0 \\
E & 1000 & 4000 & 0,5 \\
F (white control) & 0 & 5000 & 0 \\
\hline
\end{tabular}

PBS $=$ phosphate buffer solution

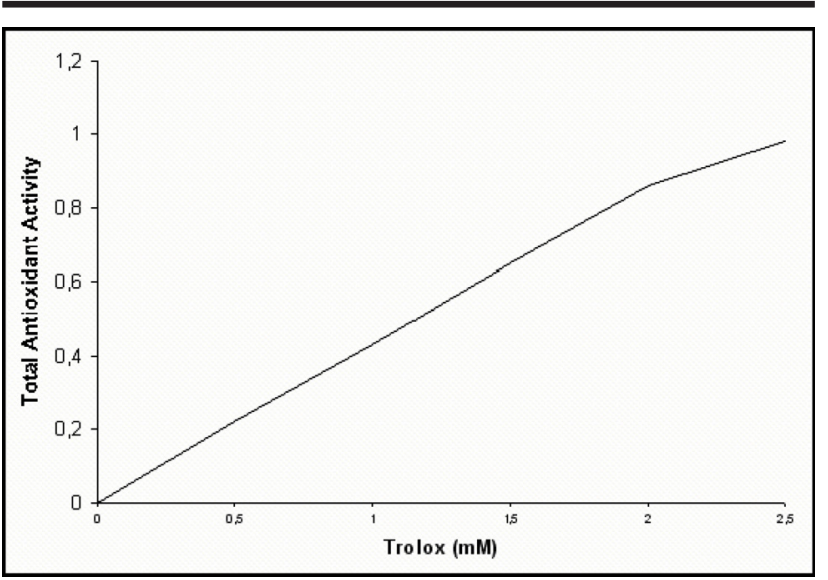

FIGURE 1 - Standard curve of the Trolox total antioxidant activity according to its concentration (mM). Conditions: $2970 \mu 1$ ABTS $^{++}, 30 \mu 1$ trolox, temperature $25^{\circ} \mathrm{C}$, time of reaction: 5 minutes.

\section{Serum total Trolox equivalent antioxidant capacity}

Measurements were done in duplicate following the same protocol used for the standard curve. The total antioxidant activity (TAA) was calculated by the formula:

$$
\mathbf{T A A}=\left(\frac{\mathrm{T}_{\mathrm{a}}-\mathrm{T} 5_{\mathrm{a}}}{\mathrm{T}_{\mathrm{a}}}\right)=\left(\frac{\mathrm{T} 0_{\mathrm{b}}-\mathrm{T} 5_{\mathrm{b}}}{\mathrm{T} 0_{\mathrm{b}}}\right)
$$

$\mathrm{T} 0_{\mathrm{a}}$ and $\mathrm{T} 5_{\mathrm{a}}$ are the serum samples, and $\mathrm{T} 0_{\mathrm{b}}$ and $\mathrm{T} 5_{\mathrm{b}}$ are the white control. The best-fit line equation was determined by the standard curve (concentration from 1.0 to $2.0 \mathrm{mM}$ of trolox) and then obtained the serum equivalent antioxidant capacity in relation to the concentration of trolox. . TEAC (trolox equivalent antioxidant capacity) was defined as the standard unity for the total antioxidant capacity of all samples.

\section{Statistical analysis}

Data was analyzed by the Kolmogorov-Smirnov test for normality and by the Levene's test to assure homogeneity. The Kruskal-Wallis was used for comparisons between groups and the Mann-Whitney test used if any statistical significance was found. A level of $5 \%(\mathrm{p}<0.05)$ was established as significant. Data was expressed as median and range.

\section{Results}

One animal of the sham group died during the experiment. The total Trolox equivalent antioxidant capacity was significantly greater in the glutamine group than both the controls $(1,60[1,55-1,77]$ vs $1,44[1,27-1,53]$, $\mathrm{p}<0,05)$ and sham group $(1,60[1,55-1,77]$ vs $1,48[1,45-$ $1,59], \mathrm{p}<0,05)$. There was no difference between sham and control groups $(p=0.10)$. These data can be seen in figure 2 .

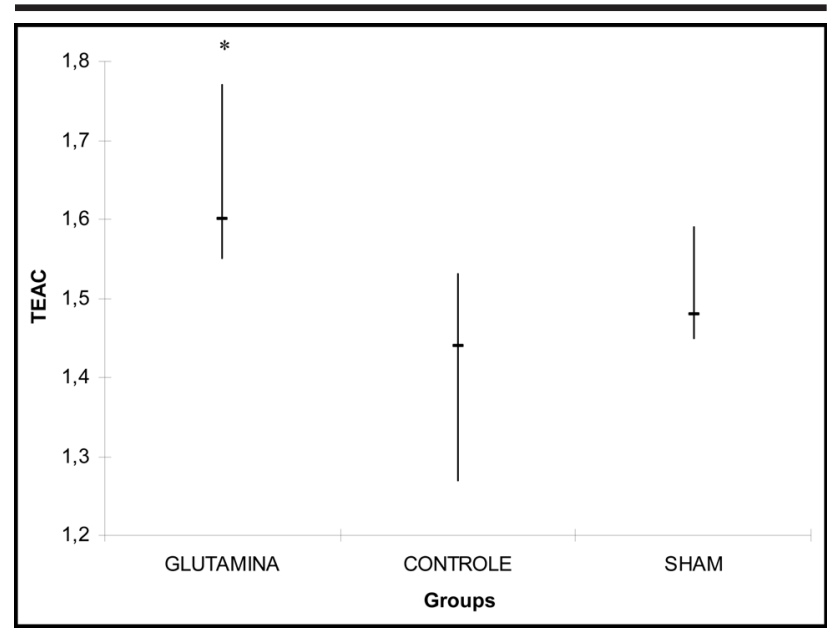

FIGURE 2 - Median (range) of the serum trolox total equivalent antioxidant capacity (TEAC) in the three groups. ${ }^{*} \mathrm{p}<0,05$ vs CONTROL and SHAM. 


\section{Discussion}

In the present study we used a method that is able to assess the total antioxidant capacity of biological samples as serum, saliva, urine, tissues, etc. The antioxidant potential was assessed by its equivalence to a known potent antioxidant - Trolox (6-hydroxy-2,5,7,8tetramethylchromane-2-carboxylic acid) which is a synthetic analogue of vitamin $\mathrm{E}^{17,19}$. The method is frequently used in the current literature ${ }^{1},{ }^{2}$. The regression analysis used to determine the best-fit line was also already used by other author ${ }^{21}$. The reference values for the serum antioxidant capacity have been considered as ranging from 1.32 to $1.58 \mathrm{mM}(1,46 \pm 0,14 \mathrm{mM})^{23}$. The method has been used for humans and for other mammals $)^{3}$. In this study the median total antioxidant capacity of rats was $1,52(1,27$ - 1,77) mM.Oxidative stress can be described as a condition resulting from an uncontrolled increase in free oxygen radicals or an insufficiency in the antioxidant system under certain pathological states. Free oxygen radicals have important toxic effects; chiefly the hydroxyl radical and to a lesser extent the superoxide anion lead to peroxidation of membrane lipids thereby causing production of malonil-dialdehyde (MDA) ${ }^{4} 4$ Percário S. Alterações oxidativas e da defesa antioxidante no broncoespasmo agudo induzido em cobaias. São Paulo (SP), Tese de Doutorado - UNIFESP-EPM, 2000. These substances directly induce tissue damage with generation of pro-inflammatory cytokines. The best known components of the endogenous antioxidant system are SOD, catalase, glutathione peroxidase, reduced glutathione, and glutathione transferase $\mathrm{e}^{8-10}$. Our finding showed a higher antioxidant capacity in the serum of animals receiving glutamine. This suggests that glutamine may increase the antioxidant defense. This might occur by the antioxidant properties of this amino acid or due to its conversion to glutathione which is a major cellular scavenger and part of the antioxidant system of the organism ${ }^{4-10}$. We have not found any other similar study for comparisons. Thus further studies are necessary to confirm these results. The overall results allow us to conclude that durind experimental ischemiareperfusion injury of the liver the presence of glutamine at the intraluminal space of the gut increases the serum total antioxidant capacity. These findings may suggest that immune diets containing glutamine may be helpful in cases of ischemia followed by reperfusion.

\section{References}

1. Eltzschig HK, Collard CD. Vascular ischaemia and reperfusion injury. Br Med Bull. 2004; 19(70): 71-86.

2. Pringle JH. Notes on the arrest of hepatic hemorrhage due to trauma. Ann Surg. 1908; 48: 541-9.

3. Silva Jr., Centurion S, Pacheco EG, Brisotti JL, Oliveira $\mathrm{AF}$, Sasso KD. Aspectos básicos da lesão de isquemia e reperfusão e do pré-condicionamento isquêmico. Acta Cir Bras. 2002; 17(3): 96-100.

4. Granger DN, Hollwarth ME, Parks DA. Ischemiareperfusion injury: role of oxygen-derived free radicals. Acta Physol Scand Suppl. 1986; 548:47-63.

5. Cymrot M, Percario S, Ferreira, LM. Oxidative stress and total antioxidant status in ischemic skin flaps in rats. Acta Cir. Bras. 2004; 19(1):18-26.

6. Hinder RA, Stein HJ. Oxygen-derived free radicals. Arch Surg. 1991;126(1):104-5.

7. Evans MA, Shronts EP. Intestinal fuels: glutamine, short-chain fatty acids, and dietary fiber. J. Am. Diet. Assoc.1992; 92:1239-46.

8. Souba WW, Smith RJ, Wilmore DW. Glutamine metabolism by the intestinal tract. JPEN 1985; 9:608-17.

9. Martensson J, Lai JC, Meister A. High-affinity transport of glutathione is part of a multicomponent system essential for mitochondrial function. Proc Natl Acad Sci USA. 1990; 87(18):7185-9.

10. Aguilar-Nascimento JE, Gurgel Marques C, Carvalho Mariano A, Bicudo Salomao A, de Souza Neves J. Benefits of intraluminal injection of glutamine for intestinal mucosa during ischemia-reperfusion. Eur Surg Res. 2003; 4:352-6.

11. Thumham DI, Situnayake RD, Kootathep S, McConkey B, Davis M. Antioxidant status measured by the TRAP assay in rheumathoid arthrits. In: RiceEvans C (editor), Free radicals, Oxidative stress and drug action. Richelieu Press. London. 1987; 169-91.

12. Writehead TP, Thorpe GHG, Marshall SRJ. Enhanced chemiluminescent assay for antioxidant capacity in biologic fluids. Analytica Chimca Acta. 1992; 266:265-77.

13. Cao G, Prior RL. Camparasion of different analytical methods for assessing total antioxidant capacity of humam serum. Clinical Chemistry. 1998; 44(6):1309-15.

14. Wayne DDM, Burton GW, Igold KU, Locke S. Quantitative measurement of the total peroxyl radicaltrapping antioxidant capacity of humam blody plasma by controlled peroxidation. FEBS lett. 1985; 187:33-7.

15. Glazer AN, Phycoerythrin fluorescence-based assay for reactive oxygen species. Methods Enzymol. 1990; 186:161-68.

16. Ghiseli A, Serafini M, Maiani G, Assini E, Ferro-Luzzi A. A fluorescence-based method for measuring total plasma antioxidant capacity. Free Rad Biol Med. 1994; 18:29-36. 
17. Miller N, Rice-Evans C, Davies M, Gopinathan V, Milner A. A novel method for measuring antioxidant capacity and its application to monitoring the antioxidant status in premature neonates. Clin Sci. 1993; 84:407-12.

18. Cao G, Verdon CP, Wu AHB, Wang H, Prior RL. Automated oxygen radical absorbance capacity assay using COBAS FARA II. Clin Chem. 1995; 41:1738-44.

19. Re R, Pellegrini R, Proteggente A, Pannala A, Yang M, Rice-Evans C. Antioxidant activity applying an improved ABTS radical cation decolorization assay. Free Rad Biol Med. 1999; 26:1231-37.

20. Romay C, Pascual C, Lissi EA. The reaction between ABTS radical cátion and antioxidants and its use to evaluet the antioxidant status of serum samples. Braz J Med Biol Res 1996; 29:175-83.

21. Miller N, Rice-Evans C (1996) Spectrophtometric determination of antioxidant activity. Redox Rpt 2:161-71.

22. Llesuy S, Evelson P, Campos AM. Methodologies for evaluation of total antioxidant activities in complex mixtures. A critical review. Biol. Res. 2001; 34(2):.51-73.

23. Rice-Evans C, Miller NJ. Total antioxidant status in plasma and body fluids. Methods Enzymol. 1994;234:279-93.

24. Rice-Evans CA. Measurement of total antioxidant capacity as a marker of antioxidant status in vivo: procedures and limitations. Free Rad Res. 2000; 33:59-66.

25. Percário S. Alterações oxidativas e da defesa antioxidante no broncoespasmo agudo induzido em cobaias. São Paulo (SP), Tese de Doutorado UNIFESP-EPM, 2000.

\section{Correspondence:}

Jose Eduardo de Aguilar-Nascimento

Rua Estevão de Mendonça, 81 - Apto. 801

78043-300 - Cuiabá - MT - Brazil

e-mail: aguilar@terra.com.br
Conflito de interesses: nenhum Fonte de Financiamento: nenhuma

\section{How to cite this article:}

Salomão AB, Aguilar-Nascimento JE, Percário S, Sano V, Marques NR, Dias CCGO. Intestinal intraluminal injection of glutamine increases trolox total equivalent antioxidant capacity (TEAC) in hepatic ischemia-reperfusion. Acta Cir Bras. [serial on the Internet] 2006;21 Suppl 4. Available from URL: http://www.scielo.br/acb. 